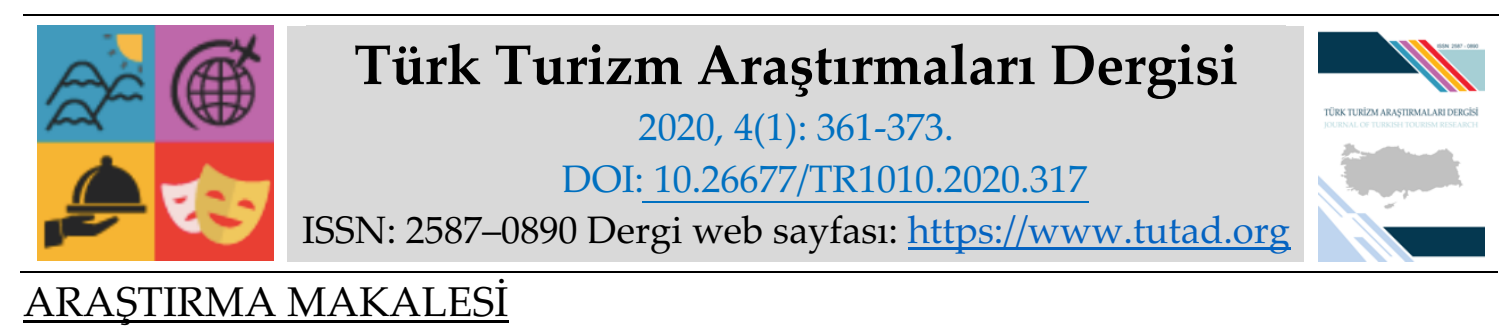

\title{
Sürdürülebilir Gastronomi Turizmi Kapsamında Somut Olmayan Kültürel Miras Unsuru: Hıdırellez Pilavı Üzerine Bir Araştırma
}

Dr. Öğr. Üyesi Çiğdem ÖZKAN, Çanakkale Onsekiz Mart Üniversitesi, Ayvacık Meslek Yüksekokulu, Çanakkale, e-posta: cigdemozkan@comu.edu.tr

ORCID: https://orcid.org/0000-0002-9823-4117

Öz

Somut olmayan kültürel mirasa dahil olan öğeler son zamanlarda artmaktadır. Bu konuda, UNESCO insanlığa ait değerlerin korunması konusunda üyesi ülkelere önemli destekler sunmaktadır. Bu çalışmada amaç, Ayvacık ilçesine bağlı hangi köylerde Hıdırellez kutlamalarında "Hıdırelez Pilavı" yapımının devam ettiğinin, sürdürülebilir gastronomi turizmine katkısının ortaya çıkarılması ve reçetesinin verilmesidir. Bu amaca bağlı olarak Ayvacık' a bağlı köylerde araştırma yapılmıştır. Alan araştırması sonucunda; Hıdırellez kutlamalarında yapılan Hıdırellez pilavının Ayvacık'a bağlı 34 köyde halen yapıldığı, 29 köyde ise geçmişte yapıldığı fakat günümüzde terk edildiği sonucuna ulaşılmıştır. Hıdırellez kutlamalarının yapılmamasında en büyük etken köylerde nüfusun ve özellikle genç nüfusun azalması olarak gösterilmektedir. Geleneklerin gelecek kuşaklara aktarımında gençlerin önemli bir yere sahip olduğu söylenebilir. Ayvacık'a bağlı 34 köyde yapılan Hıdırellez kutlamalarında nişanlı kıza kuzu veya oğlak götürüldügü ve Hıdırellez pilavı yapıldığı sonucuna ulaşılmıştır. Hıdırellez kutlamalarına Ayvacık'a bağlı Türkmen köylerinde daha çok önem verildiği, yapılan yöresel yemeklerin sunumu ve yapımında tüm köy halkının birlikte hareket ettiği ifade edilebilir. Hıdırellez kutlamalarına civar köylerin, ilçe merkezinde yaşayan kişilerin ve dışarıda yaşayan köylülerin katıldıkları, kutlamalarının olduğu gün veya günlerde köylerinin kalabalıklaştığını ifade etmişlerdir. Bununla beraber yabancı turistlerin kutlamalara çok fazla ilgi göstermedikleri bunun nedeninin ise tanıtım eksikliği olduğu ifade edilmiştir.

Anahtar Kelimeler: Somut Olmayan Kültürel Miras, Hıdırellez Pilavı, Yerel Gastronomi, Sürdürülebilir Turizm

Makale Gönderme Tarihi: 18.10.2019

Makale Kabul Tarihi: 06.01.2020

\section{Önerilen Atıf:}

Özkan, Ç. (2020). Sürdürülebilir Gastronomi Turizmi Kapsamında Somut Olmayan Kültürel Miras Unsuru: Hıdırellez Pilavı Üzerine Bir Araştırma, Türk Turizm Araştırmaları Dergisi, 4(1): 361-373.

(C) 2020 Türk Turizm Araştırmaları Dergisi. 


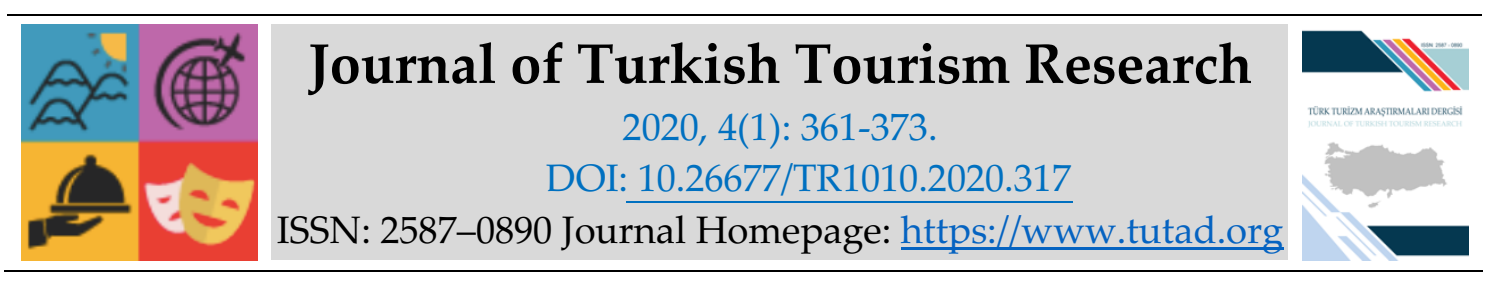

RESEARCH PAPER

\title{
The Intangible Cultural Heritage in The Scope of Sustainable Gastronomy Tourism: A Research on Hidırellez Rice
}

Assistant Prof. Dr. Çiğdem ÖZKAN, Çanakkale Onsekiz Mart University, Ayvacık Vocational School, e-mail: cigdemozkan@comu.edu.tr

ORCID: https://orcid.org/0000-0002-9823-4117

\begin{abstract}
Recently, new elements are included in intangible cultural heritage elements. In this regard, UNESCO offers significant support to its member countries in the protection of human values. The aim of this study is to reveal and prescribe in which villages of Ayvacik "Hidirellez rice" during the "Spring Festival Hidırellez" celebrations are made today. For this aim, research has been conducted in the village of Ayvacik. As a result of the field research; It was concluded that Hidırellez rice, which was made during the Hidırellez celebrations, was still made in 34 villages of Ayvacik, and in 29 villages it was made in the past but was abandoned today. The biggest factor in the absence of Hidirellez celebrations in villages is the decrease in the population and especially the young population in the villages. It can be said that young people have an important place in transferring traditions to future generations. In the Hidirellez celebrations held in 34 villages of Ayvacık, it was concluded that the engaged girl was taken to lamb or kid and the Hidirellez rice was made. It can be stated that Hidirellez celebrations are given more importance in the Turkmen villages of Ayvacik and that all the village people act together in the presentation and construction of the local dishes made during the celebrations. Hidirellez celebrations of the surrounding villages, people living in the district center and outside villagers participated in the celebrations, stated that the days or days of the village was crowded. However, it was stated that foreign tourists did not show much interest in the celebrations because of the lack of publicity.
\end{abstract}

Keywords: Intangible Cultural Heritage, Hidırellez Rice, Local Gastronomy, Sustainable Tourism

Received: 18.10 .2019

Accepted: 06.01.2020

Suggested Citation:

Özkan, Ç. (2020). The Intangible Cultural Heritage in The Scope of Sustainable Gastronomy Tourism: A Research on Hidırellez Rice, Journal of Turkish Tourism Research, 4(1): 361-373.

(C) 2020 Türk Turizm Araştırmaları Dergisi. 


\section{Gíriş}

Somut olmayan kültürel miras, göreceli olarak yeni bir konsept olmasına rağmen, geçmiş yarım yüzyıldan beri önemli gelişim içerisindedir. Kısa adı UNESCO olan Birleşmiş Milletler Eğitim, Bilim ve Kültür Kurumu'nun Paris'te 29 Eylül-17 Ekim 2003 tarihler arasında toplanan 32. Genel Konferansı, 17 Ekim 20031972 tarihli "Somut Olmayan Kültürel Mirasın Korunması Sözleşmesi'ni kabul etmiştir. Sözleşme, TBMM'nin 19.01.2006 tarihli oturumunda oy birliği ile kabul edilmiştir. Kasım 2018 tarihi itibari ile Türkiye'nin İnsanlığın Somut Olmayan Kültürel Miras Temsili Listesine kayıtl 16 adet unsur bulunmaktadır. Bahar Bayramı Hıdırellez, UNESCO insanlığın somut olmayan kültürel miras temsili listesine 2017 yılında girmiştir (UNESCO Türkiye Milli Komisyonu, 2019). Somut olmayan kültürel mirasa ait değerlerin ortaya çıkarılması ve korunması UNESCO ve UNWTO gibi kültür ve turizmin korunması ve geliştirilmesinden sorumlu uluslararası örgütler tarafından, ulusal ve kültürel kimliği teşvik etmenin ve geliştirmenin bir yolu olarak görülmektedir.

Bir topluma veya topluluğa ait folklorik değerler, o toplumun somut olmayan kültürel mirasının ifadesi olarak görülmektedir. Somut olmayan kültürel miras; yerel ürünler, sanatlar, sosyal uygulamalar, ritüeller, festivaller, bayramlar, ulusal ve evrensel bilgi ve beceriler ile üretilen geleneksel sanat ürünlerinin gibi unsurları içermektedir (Kurin, 2004). Bir topluluğun yeme-içme özellikleri, sunum şekilleri 2010 yılından itibaren UNESCO tarafından somut olmayan kültürel miras listesinde yer almaktadır. Örneğin "Geleneksel Tören Keşkeği", "Mesir Macunu Festivali", "Türk Kahvesi ve Geleneği”, "İnce Ekmek Yapımı ve Paylaşımı Geleneği”, UNESCO tarafından, insanlığın somut olmayan kültürel miras temsili listesinde yer alan gastronomi değerleridir. Böylece bir topluluğa ait gastronomi değerleri, sunum şekilleri, yeme özellikleri o topluluğun gastronomi mirası içerisinde değerlendirilmektedir. Günümüzde önemli sayılabilecek oranda bir bölgedeki gastronomi değerlerini tatmaya giden turist olduğu ifade edilmektedir (Ayaz ve Çobanoğlu, 2017; Bezirgan ve Koç, 2014; Zağralı ve Akbaba, 2015).

Hıdırellez bir mevsim bayramıdır (Kahraman ve Arıkan, 2015; Önal, 2010; Çay, 1999, Kumartaşlığlu, 2017: 267). Hidırellez inancının temelinde soğukların bitmesi ve baharın gelmesi, tabiatın canlanması fikri hakimdir (Çalışkan, 2015: 390). Özellikle doğa ile iç içe yaşayan toplayıcı, avcı ve temel geçim kaynağı tarım ve hayvancilık olan toplumlarda mevsim bayramları oldukça önemlidir (Kahraman ve Arıkan, 2015). Hıdırellez, ölümsüzlüğe ulaşmış Hızır ve İlyas peygamberlerin bir su kenarında veya gül ağacı altında buluşma günü olarak bilinir. "Hızır karalarda, Ilyas ise denizlerde zor durumda olan insanlara yardıma koşar" inancı, bu bayramı kutlayan bütün toplulukların ortak kültürel değerdir (Çetin, 2002: 30).

Türklerde Hıdırellez, İran coğrafyasında "Mihrican", Hıristiyanlık dünyasında da "Paskalya", mevsim bayramlarına örnek gösterilmektedir. Türklerin eskiden beri Hıdırellez şenliklerine yoğun ilgi göstermektedir (Çalışkan, 2015: 390). Tarım ve hayvancılıkla uğraşan yerleşik yapama geçmiş ilk topluluklardan olan Türk toplumunda Hıdırellez bayramının kutlanması şaşırtıcı görülmemektedir. Türklerde bir gelenek haline gelmiş Hıdırellez bayramında birçok ritüelin olduğu bilinmektedir. Hıdırellez gününe özel yapılan yemeklerde bu ritüellerden yalnızca bir tanesidir. Bulunan şehre ve hatta köye göre sunulan yemekler çeşitlilik göstermektedir. Bunun yanı sıra baharın gelişinin kutlanmasında birlik ve beraberliğin pekiştirildiği görülmektedir.

Günümüzde Hıdırellez kutlamaları Türkiye'nin birçok il ve ilçesinde yapılmakla birlikte her bölgeye ve yöreye özgü geleneksel kutlama biçimlerinden ve geleneksel yemeklerden söz edilebilir. Önal (2010) “Muğla' da Hıdırellez Bayramı” adlı çalışmasında Muğla iline bağlı birçok köyde Hıdırellez Bayramının kutlandığını ve uygulamaların ve yemeklerin çeşitlilik arz ettiğini ifade etmiştir. 
Zengin bir kültüre sahip olan Ayvacık ilçesine bağlı bazı köylerde her yıl Bahar Bayramı Hıdırellez kutlamaları yapılmakta ve kutlamalarda "Hıdırellez Pilavı" yapılmaktadır. Bu çalışmada amaç, Ayvacık ilçesine bağlı hangi köylerde Hıdırellez kutlamalarında "Hıdırellez Pilavı" yapımının devam ettiğinin, sürdürülebilir gastronomi turizmine katkısının ortaya çıkarılması ve reçetesinin verilmesidir. Bu amaca bağlı olarak, Ayvacık ilçesine bağlı köylerde muhtarlar ve yerel halk ile görüşmeler yapılmıştır. Hıdırellez kutlamalarında yapılan Hıdırellez pilavının reçetesinin verilmesi, Ayvacık'a bağlı hangi köylerde halen geleneğinin devam ettiğinin ortaya çıkarılması ve sürdürülebilir gastronomi turizmine katkısının tartışılması bu çalışmanın önemini oluşturmaktadır.

\section{KAVRAMSAL/KURAMSAL ÇERÇEVE}

UNESCO (2003) tarafından somut olmayan kültürel miras, kültürel mirasın bir parçası olarak kişiler tarafından uygulanan sunumlar, ifadeler, bilgi ve beceriler olarak tanımlanmaktadır. Vanhonacker vd., (2010: 453) geleneksel gastronomiyi aşağıdaki şekilde tanımlamıştır: "geleneksel yiyecek ürünü, belirli bir yere, bölgeye ya da ülke ait olan, nesilden nesile aktarılan, doğal olarak işlenen ve duygusal özelliklerinden dolayı ayırt edilen ve bilinen özel kutlamalarda ve/veya dönemlerde sıklıkla sunulan, özel bir şekilde yapılan, doğal bir üretim süreci olan bir üründür". Benzer şekilde, Barrere vd. (2012), "gastronomi mirasının yeme içme biçimini içerdiğini" ifade etmektedirler.

Festivaller, geleneksel etkinlikler, yöresel el sanatları ürünleri, diğer somut olmayan kültürel miras unsurları (yöresel yemekler gibi) ulusal, bölgesel ve uluslararası düzeyde turist çekmeye yarayan güçlü unsurlardır. Bu turistik ürün ve faaliyetler yeni iş ve gelir yaratma etkisinin yanı sıra, yerel toplumların gurur duymaların sağlamaktadır. Bunun yanı sıra salt turizmden gelir elde etme amaciyla yapılan faaliyetlerin uzun vadede somut olmayan kültürel miras unsurlarını risk altında bıraktığ 1 ifade edilebilir. Bu nedenle turizm ile ilgili faaliyetlerin, somut olmayan kültürel mirasa zarar vermemesi için kamu, özel sektör ve yerel halk tarafından mı yapılması gerektiği tartışılabilir.

Dünyada bütün toplumlar kendilerine özgü mutfak kültürüne ve beslenme biçimlerine sahiptir (Serçeoğlu, 2014). Günümüzde yerel yiyecekler ve içecekler birçok turistin destinasyon seçiminde ana motivasyon kaynağı olduğu ifade edilmektedir (Ayaz ve Çobanoğlu, 2017). Bunun yanı sıra Bayrakçı ve Akdağ (2016) yerel yemek tüketimin turistlerin tekrar ziyaret etme niyetlerini olumlu etkilediğini ifade etmektedir.

Yöresel yemekler bir bölgenin sahip olduğu kimliğin bir ifadesidir ve bölge kültürünün bir parçasıdır. Bu nedenle yöresel mutfak kültürü ile tanışan ziyaretçiler yerel kültür ile ilgili bilgi sahibi olmaktadırlar (Lee, 2014: 20). Bir bölgedeki yemek kültürü o bölgede yaşamın başlamasıyla beraber başlayan ve yüzyıllar boyu birikerek devam eden yaşayan bir kültürel mirastır. Yemek kültürü, hayatta olmayan insanların yaşamış olduğu topraklardaki gelenek, görenek, dini inanışlar, inançlar, sosyal ve ekonomik koşullar gibi birçok faktör tarafından şekillenmektedir (Wahlqvist ve Lee, 2007: 2). Yemek kültürü, bireyin kim olduğu ve nereye ait olduğu hakkında bilgi vermektedir (Delind, 2006: 136). Hidırellez pilavı, Hıdırellez kutlamalarında yapılan, kültürel değeri olan yöresel bir yemektir.

Hızır karada, İlyas ise denizde yaşayan bir peygamberdir. Bolluk, bereket, şifa ve uğur getirmek için buluşurlar. Hızır ve İlyas peygamberlerin 5 Mayıs' 6 Mayıs'a bağlayan gecede birleştiğine inanılır. 6 Mayıs Hıdırellez bayramı olarak kutlanır. Hıdırellez'de genellikle pikniğe gidilir. Yeşillik alanlarda, su kenarlarında, bir türbe ya da yatırın yanında kutlanır. Bu yerlere bu nedenle "Hıdırlık" da denilmektedir. Hıdırellez gününün yiyecekler bakımından önemi vardır. Osmanlı 
döneminde yeni doğmuş kuzulara bugüne kadar dokunulmazmış. Bütün Müslümanlar Hıdırellez'de maddi olanaklarına göre kuzu alır ve kuzu eti pişirilirmiş. Bu nedenle kuzu eti ile yapılan yemekler geleneksel sayılmaktadır. Hıdırellez kutlamalarında bölgelere göre yemek çeşitleri farklılık göstermektedir. Bu çalışmada Ayvacık ilçesi ve bağlı köylerinde yapılan Hıdırellez pilavı ile ilgili bilgilere yer verilmektedir. Köylerde Hıdırellez pilavı adı altında yemek yapılmakta ve hep beraber yenilmektedir.

Hıdırellez günü, topluluk halinde hep birlikte yenilen yemeklere Hıdırellez yemekleri dinilmektedir (Önal, 2010: 7). Köylerde "Hıdırellez pilavı" adı altında hayır yemeği verilmektedir (Erol 2004: 112-113). Bu yemeğe başka yerlere göçen eski köy sakinleri de çağrılmakta böylece köyünü ziyaret etmek için bir sebep oluşturulmaktadır. Bu nedenle bazı köylerde Hıdırellez kutlamaları genellikle hafta sonlarına denk getirilmektedir. Kahraman ve Arıkan (2015: 16). Bilecik'te Hıdırellez kutlamalarında Hıdırellez pilavının yapıldığı ve köyde yaşayanlar ve köyden göç edenlerin davet edilerek birlik, dayanışma ve kardeşlik duygularının canlandırıldığ ifade edilmektedir. Kahraman ve Arıkan (2015) yaptıkları çalışmada "Hıdırellez Pilavı" uygulamasının günümüzde Bilecik'te büyük katılımlar ile canlı bir şekilde sürdürüldüğü sonucuna ulaşmıştır. Hıdırellez bir bayram olarak kutlanmaktadır. Hıdırellez kutlamalarında, Hıdırellez gününe özel yemekler yapılmakta olup çeşitli etkinler ile kutlanmaktadır (Önal, 2010).

Günümüzde yöresel gastronomi değerlerini tatmak, tanımak amacıyla turizm faaliyetlerinde katılan bir turist kitlesinden bahsetmek mümkündür. Hatta Türkiye' de bazı şehirler (Gaziantep gibi.) gastronomi kenti unvanı almıştır. Hal böyle iken yöresel yemeklerin ve yöresel kültürel değerlerin turistik ürün olarak kullanımı gün geçtikçe artmaktadır. Yerel yemeklerin tatilin kalitesi açısında önemli olduğu düşünülmektedir (Gheorghe, Tudorache ve Nistoreanu, 2014). Gastronomi turizmi "gastronomi ürünlerinin birincil ve ikincil üreticilerini, gastronomi festivallerini, fuarları, etkinlikleri, yemek pişirme gösterilerini, yiyeceklerin lezzet testlerini veya yiyecekle ilgili her türlü etkinliğe yapılan ziyaretlerin dahil olduğu, boş zamanı değgrlendirmek veya eğlenceli bir zaman yaşamak için zengin gastronomi kaynaklarına sahip bölgelere yapılan seyahatler olarak" tanımlanmaktadır (Lee, Packer ve Scott (2015). Sürdürülebilir gastronomi turizmi ise, yerel gastronomi değerlerinin gelecek kuşakları tarafından bilinir kılınması için reçetelerinin oluşturulması, kayıt altına alınması ve geçmişten gelen hazırlama ve pişirme yöntemlerine sadık kalarak turizm amaçlı kullanılması olarak tanımlanabilir.

\section{METERYAL VE YÖNTEM}

\section{Araştırmanın Amacı ve Önemi}

Bu çalışmada amaç, Ayvacık ilçesine bağlı hangi köylerde Hıdırellez kutlamalarında "Hıdırelez Pilavı" yapımının devam ettiğinin, sürdürülebilir gastronomi turizmine katkısının ortaya çıkarılması ve reçetesinin verilmesidir. Bu amaca bağlı olarak Ayvacık ilçesine bağlı köylerde muhtarlar ve yerel halk ile görüşmeler yapılmıştır. Çalışmanın amacına yönelik olarak hazırlanan görüşme soruları aşağıdaki üç temaya cevap bulmaya yönelik olarak hazırlanmıştır.

Yöresel bir gastronomi değeri olan Hıdırellez pilavının sürdürülebilirliğinin sağlanması, gelecek kuşaklara farklılaşmasını engelleyebilmek ve için standart reçetesinin belirlenmesi bu çalışmanın önemini oluşturmaktadır. Aydoğdu ve Mızrak (2017) yöresel yiyeceklerin standart reçeteler ile kayıt altına alınması gerektiğini, böylelikle mutfağa ait kültürel miraslarımızın aslına sadık şekilde korunup kuşaktan kuşağa aktarılmasına ve yaşatılabilmesine büyük katkı sağlayacağını belirtmişlerdir.

Tema 1: Hıdırellez kutlamaları geleneği sürdürülebilirliği 
Tema 2: Hıdırellez pilavının sürdürülebilir gastronomi turizme katkısı

Tema 3: Hıdırellez pilavı ve nişanlı kıza kuzu veya oğlak götürülmesi

Ayvacık ilçesi bağlı köylerde yüz yüze görüşme ve gözlem yöntemiyle yaptığımız araştırmalar ve daha önce yapılan çalışmalar bu çalışmanın kaynağını oluşturmaktadır.

\section{Araştırma Deseni ve Soru Formunun Oluşturulması}

Bu çalışmada nitel araştırma desenlerinden olan "durum çalışması deseni" kullanılmıştır. Nitel durum çalışması, bir duruma ilişkin etkenlerin (ortam, bireyler, olaylar, süreçler vb.) bütüncül bir bakış açısı ile incelenmesi ve ilgili durumun etkilerinin nasıl olduğunun ve ilgili durumu nasıl etkilediklerinin araştırılmasıdır (Yıldırım ve Şimşek, 2011). Araştırmada görüşmecilere üç soru yöneltilmiştir. Hazırlanan sorular literatür incelenerek oluşturulmuştur. Görüşmecilere köylerinde Hıdırellez kutlamalarının yapılıp yapılmadığı, yapılan kutlamada Hıdırellez pilavının yapılıp yapılmadığı, Hıdırellez kutlamalarında yerli veya yabancı turistlerin olup olmadığı ile ilgili sorular yöneltilmiştir.

\section{Evren ve Örneklem}

Çalışmada evren Ayvacık ilçesine bağlı köylerde yaşayan kişilerden oluşmaktadır. Bölgenin araştırma alanı olarak seçiminde kökleri milattan öncesine dayanan yerleşim yerlerinin bulunması dolayısıyla zengin kültürel mirasa sahip olması, bölgede Yörük ve Türkmenlerin varlığı nedeniyle farklı ve zengin yeme-içme değerlerine sahip olması etken olmuştur. Çalışmada evrenin tamamına ulaşmak zaman ve maliyet açısından zorlu olacağından örneklem alınması tercih edilmiştir. Araştırmada, veri toplama tekniği olarak görüşme yöntemi kullanılmıştır. Örneklem grubu seçiminde köy muhtarları ve yerel halk esas alınmıştır. Örneklem seçimi gönüllülük esasına göre yapılmıştır. Köy muhtarları ile araştırma hakkında önceden görüşülmüş ve araştırma hakkında bilgi verilmiştir. Araştırmaya katılmayı kabul eden 11 kişi ile görüşme yapılmıştır. Görüşmeler, görüşmecilerin ve araştırmacının müsaitlik durumuna göre 15.04.2019 ile 10. 05. 2019 tarihleri arasında yapılmış ve veriler toplanmıştır. Tüm görüşmeler ses kayıt cihazına kaydedilmiştir.

\section{Verilerin Analizi}

Bu çalışmada verilerin analizinde "Betimsel Analiz" tekniği kullanılmıştır. Betimsel analiz, elde edilen verilerin daha önceden verilen temalara uygun biçimde özetlenmesi ve yorumlanmasıdır (Yıldırım ve Şimşek; 2011). Bunun için yapılandırılmış görüşme kayıtları oluşturulan temalara göre gruplandırılmıştır. Bununla beraber her bir soruya verilen cevap kategorileri yazılarak "Görüşme kodları anahtarı" oluşturulmuştur. Bulguların yorumlanmasında sorulara verilen cevaplar doğrudan alıntılarla desteklenmiştir.

\section{BULGULAR VE TARTIŞMA}

Çalışmanın bu kısmında görüşmecilerden elde edilen bilgiler doğrultusunda alıntılarla desteklenerek temalara ilişkin bulgulara yer verilmektedir. 


\section{Görüşme Sonuçları}

\section{Tema 1: Hıdırellez Kutlamaları Geleneği Sürdürülebilirliği}

Yapılan görüşmeler sonucunda bütün görüşmeciler tarafından; Adatepe, Ahmetçe, Babadere, Bektaş, Bilaller, Büyükhusun, Çamkalabak, Çamköy, Çınarpınar, Demirci, Dibekli, Güzelköy, İlyasfaki, Keçikaya, Kestanelik, Kısacık, Kızılkeçili, Kocaköy, Korubaşı, Küçükhusun, Naldöken, Paşaköy, Pınardere, Sapanca, Sazlı, Söğütlü, Süleymanköy, Şapköy, Tabaklar, Tamış, Tartışık, Tuztaşı, Uzunalan ve Yukarıköy'de Hıdırellez kutlamalarında gelin kıza oğlak veya kuzu götürülmesi ve Hıdırellez Pilavı yapımının devam ettiği ifade edilmiştir. Bunun yanı sıra, Adatepe, Ahmetler, Arıklı, Babakale, Bademli, Baharlar, Bahçedere, Balabanlı, Budaklar, Behramkale, Cemaller, Çakmaklar, Çaltı, Erecek, Hüseyinfaki, Kayalar, Kırca, Koyunevi, Kozlu, Kösedere, Kulfal, Koruoba, Misfvak, Nusratlı, Taşağıl, Taşboğaz, Tuzla, Yeniçam, Yeşilyurt köylerinde hıdırelez pilavının ve nişanlı kıza kuzu veya oğlak götürülmesi geleneğinin önceden var olduğunu fakat günümüzde sürdürülmediği ifade edilmiştir. Sonuç olarak; Hıdırellez pilavının Ayvacık'a bağlı 34 köyde halen yapıldığı, 29 köyde ise geçmişte yapıldığı fakat günümüzde terk edildiği sonucuna ulaşılmaktadır.

Görüşmeci 1,2 ve 3 Hıdırelez pilavı geleneğinin yok olmasında köylerde genç nüfusun olmamasından kaynaklandığını ifade etmiştir. Görüşmeci 10, nüfus bakımından az olan köylerde geleneğin devam etmediğini belirtmiştir. Görüşmeci 5,6,7,8, 9,11, Hıdırellez pilavı yanında diğer geleneksel yemeklerinde yapıldığını ve köyde yüksek bir tepeye veya geniş bir piknik alanına gidilerek eğlencelerin yapıldığını ifade etmiştir. Görüşmeci 5, Türkmen köylerinde Hıdırellez kutlamalarının üç gün sürdügünü ve durumu müsait olan ailelerin kuzu veya oğlak keserek Hıdırellez pilavı yaptığını ve köy halkının toplanarak yapılan tüm yöresel yemekleri yediklerini ifade etmiştir.

\section{Tema 2: Hıdırellez Pilavının Sürdürülebilir Gastronomi Turizmine Katkısı}

Yapılan görüşmeler sonucunda, görüşmecilerin tamamı Hıdırellez pilavının gerek lezzet bakımından gerek kutlamalarda yapılması bakımından turistlerin büyük ilgisini çekeceğini düşündüklerini belirtmişlerdir. Bunun yanı sıra Görüşmeci 2,3,7,9 ve 11 civar köylerin, ilçe merkezinde yaşayan kişilerin ve dışarıda yaşayan köylülerin Hıdırellez kutlamalarına katıldıkları, Hıdırellez kutlamalarının olduğu gün veya günlerde köylerinin kalabalıklaştı̆̆ını ifade etmişlerdir. Görüşmeci 2, köylerinde yaşayan yabancı turistlerin kutlamalara büyük ilgi gösterdiklerini ve yöresel yemekleri zevkle yediklerini ifade etmiştir. Görüşmeci 1, yabancıların tanıtım yapılırsa büyük ilgisinin olacağını düşündüğünü belirtmiştir.

\section{Tema 3: Hıdırellez Pilavı ve Nişanlı Kıza Kuzu veya Oğlak Götürülmesi}

Görüşmeci 1, Bahar Bayramı Hıdırellez günü nişanlı kıza erkek evinden bir kuzu veya oğlak götürülür. Bu hem bereketin hem de kıza verilen değerin bir göstergesidir. Erkek evinin varlıklı olduğunu gösteren bir durumdur. Kız evine götürülen oğlak veya kuzu, kız evi tarafından kesilir ve Hıdırellez pilavı yapılarak hep beraber baharın gelişi kutlanır. Görüşmeci 1, Sapanca köyünde bu geleneğin halen sürdürdügünü fakat eskisi kadar yaygın olmadığını ifade etmiştir.

Görüşmeci 1, 1960 yılında evlendiğini ve bir yıl nişanlı kaldığını belirtmiştir. Nişanlılık döneminde erkek evi tarafından kendisine iki kez kuzu getirildiğini ve Hıdırellez pilavı yaparak hep beraber kutlama yaptıklarını ifade etmiştir. Kendini bildiğinden beri Erecek köyünde bu geleneğin sürdüğünü ifade etmiştir. 
Benzer bir uygulama Yozgat'ta nişanlı bir çift varsa, erkek tarafı Hıdırellez'de kız tarafını alışverişe götürür, daha sonra erkek tarafı eşini dostunu çağırarak kız tarafına gider. Şerbetli su içilir, Yasin okunur ve kız ona alınan elbiseleri giyer. Ardından pikniğe gidilir, piknikte kuzu veya koyun kesilir hep birlikte yenilir içilir. Dilek ağacına dilekler dilenir (Çalışkan, 2015: 386).

Görüşmecilerin tamamı Hıdırellez pilavının yapımını bilmektedirler. Reçetesinde taze yenilebilir otların bir kısım görüşmeci tarafından verilmediği ortaya çıkmıştır. Bu nedenle yeşilliklerin reçetede isteğe bağlı olarak konulacağı belirtilmiştir. Görüşmeci 1, Hıdırellez pilavı uygulaması kendi evinde yapabileceğini belirtmiştir. Hıdırellez pilavı reçetesi ve yapım şekli aşağıdaki gibidir.

\section{Hidırellez Pilavı Malzemeler}

1 bütün kuzu

$2 \mathrm{~kg}$ pirinç

Tuz

Karabiber

Zeytinyağ 1

$\mathrm{Su}$

Maydanoz, dereotu, taze soğan (isteğe bağl1)

\section{Yapılışı}

Bütün kuzu kesilir, temizlenir ve doğranır. Kuzunun ciğerleri zeytinyağında kavrulur. Pirinç tuzlu ılık suda bekletilir. Bekledikten sonra pirinçler geniş bir tavaya alınır ve üzeri geçirilecek kadar su eklenir. Su eklenirken kaşıkla pirinçler bastırılır. Daha sonra üzerine ciğerler konur biraz tuz ve karabiber eklenir. İsteğe bağlı olarak yeşillikler eklenir. Ardından kuzunun etleri en üste dizilir. Ağaç dalları tavanın üzerine yerleştirilerek kuzu etinin yağlı kısmı (sırt bölgesi) dalların üzerine serilir ve zeytinyağı gezdirilir. Odun ateşinde (köy yerlerinde ekmek fırını) pişirilir. Fırının kapağı çamur ile bulanır ki hava almasın. Yaklaşık 4-5 saat pişirildikten sonra servis edilir.

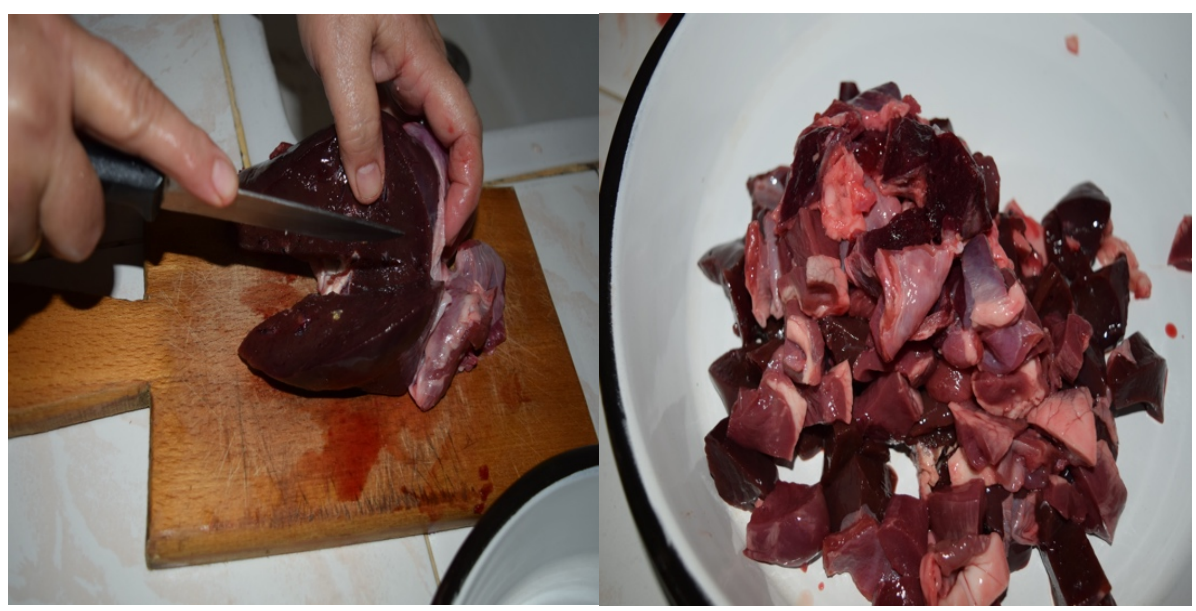

Aşama $1^{1}$

Aşama 2

\footnotetext{
${ }^{1}$ Fofoğraflar Çiğdem ÖZKAN tarafından çekilmiştir.
} 


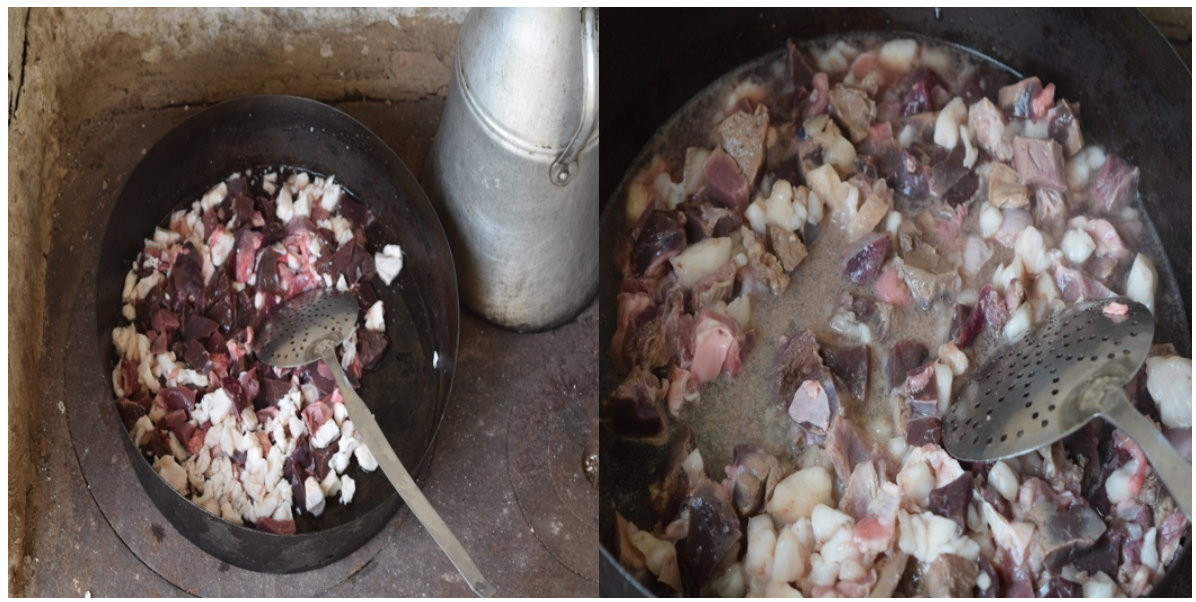

Aşama 3

Aşama 4
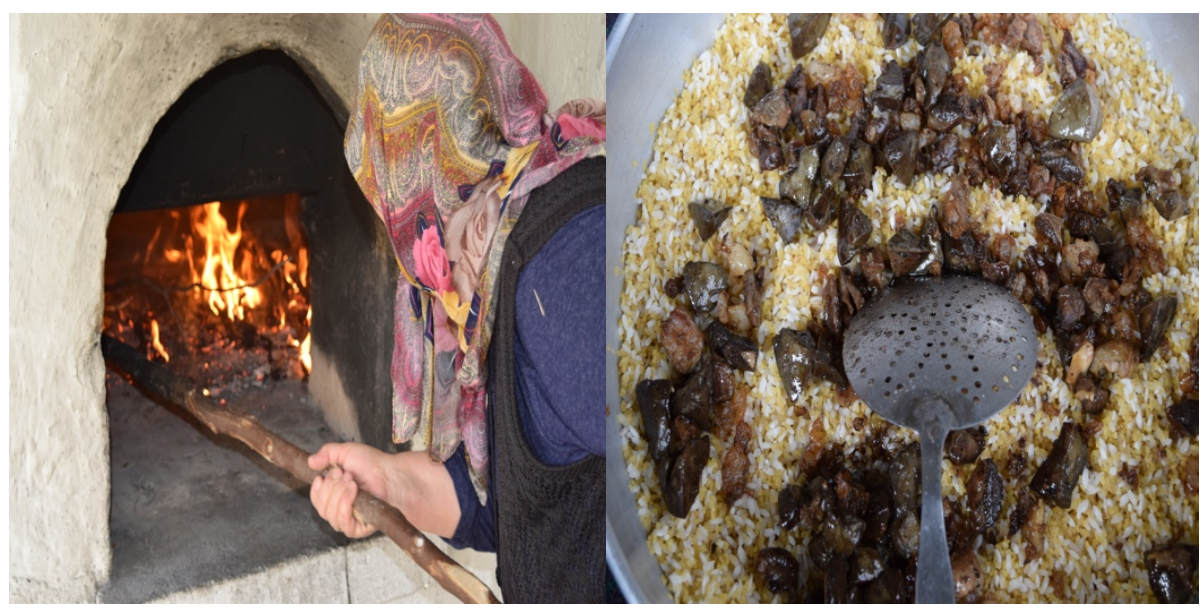

Aşama 5

Aşama 6

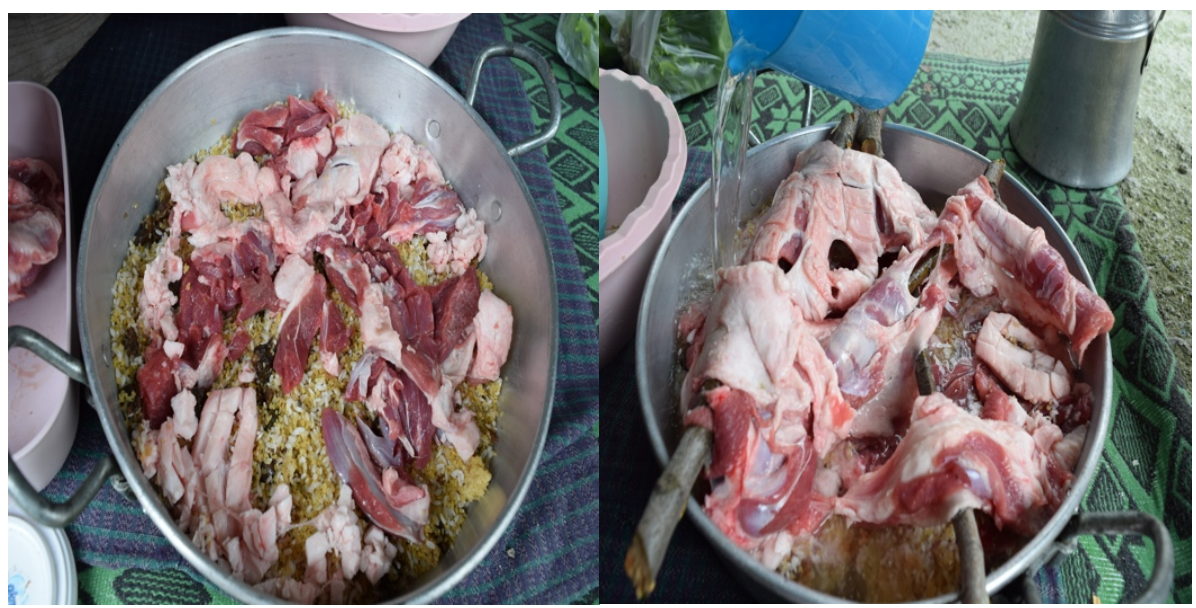

Aşama 7

Aşama 8 


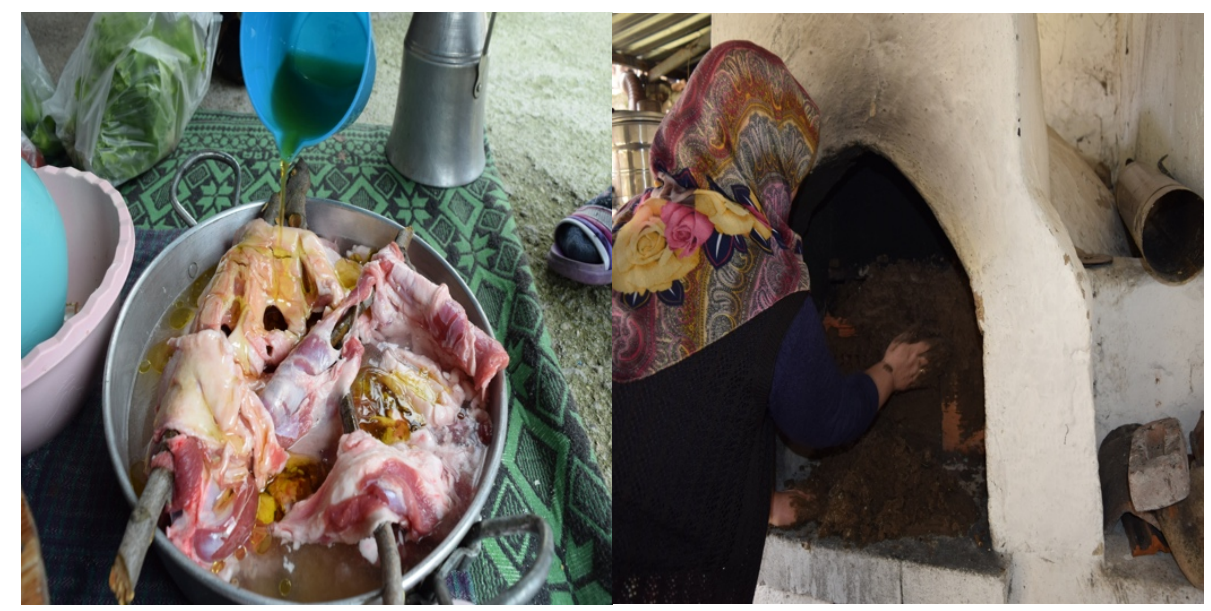

Aşama 9

Aşama 10

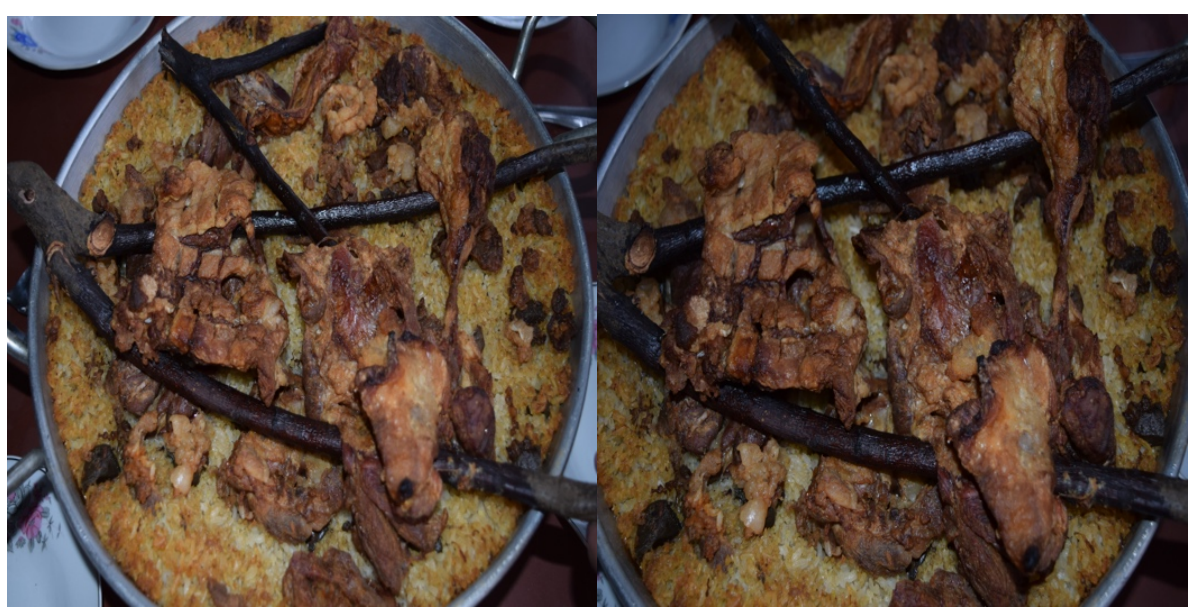

Aşama 11

Aşama 12

\section{SONUÇ VE ÖNERİLER}

Binlerce yıllık bir geçmişi olan Hıdırellez kutlamaları, Orta Asya'dan Balkanlara karar geniş bir coğrafyada yapılmaktadır. Somut olmayan kültürel miras olan Hıdırellez kutlamalarının artık eskisi kadar kutlanmamasının küreselleşmenin insanlar üzerinde yaptığı baskıların sonucu olduğu düşünebilir. Küreselleşme olarak tanımlanan gelişmelerin, köklü geçmişe sahip toplumlardaki gelenek ve görenekler üzerinde olumsuz etkileri olduğu görülmektedir. Özellikle gençlerin gelenek ve görenekleri sürdürme konusundaki isteksizliği nedeniyle insanlığa ait binlerce yıllık geçmişi olan kültürel değer üzerinde olumsuz baskı oluşturmaktadır. Bu nedenle UNESCO insanlığa ait somut olmayan kültürel mirasın korunması konusunda üye ülkelere destekler sunmaktadır. Hıdırellez kutlamaları UNESCO somut olmayan kültürel miras listesinde yer almaktadır. Hıdırellez kutlamaları günümüzde halen birçok köy ve ilçe de geçmişten gelen ritüellere uygun biçimde yapılmaktadır. Türk dünyasından bahar bayramı olarak kutlanan Hıdırellez bayraminda birlik, beraberlik ve bereketin ifadesi olarak yöresel yemekler yapılmaktadır. Yapılan yöresel yemekler çeşitlilik arz etmekle birlikte "Hıdırellez pilavının" Ayvacık ilçesine bağlı köy ve ilçe merkezinde yapıldığı ve Hıdırellez günü nişanlı kıza oğlak veya kuzu götürülerek, Hıdırellez pilavının götürülen kuzu veya oğlak ile yapıldığı yapılan görüşmeler sonucunda ortaya çıkmıştır. Hıdırellez pilavının geleneksel anlamının olması da bu yöresel yemeğe turistik bir değer kazandırılması gerektiğini düşündürmektedir. 
Alan araştırması sonucunda; Hıdırellez kutlamalarında yapılan Hıdırellez pilavının Ayvacık'a bağlı 34 köyde halen yapıldığı, 29 köyde ise geçmişte yapıldığı fakat günümüzde terk edildiği sonucuna ulaşılmıştır. Hıdırellez kutlamalarının köylerde yapılmamasında en büyük etken köylerde nüfusun ve özellikle genç nüfusun azalması olarak gösterilmektedir. Geleneklerin gelecek kuşaklara aktarımında gençlerin önemli bir yere sahip olduğu söylenebilir.

Hıdırellez kutlamalarına Ayvacık'a bağlı Türkmen köylerinde daha çok önem verildiği, kutlamalarda yapılan yöresel yemeklerin sunumu ve yapımında tüm köy halkının birlikte hareket ettiği ifade edilebilir. Bunun yanı sıra yapılan alan araştırması sonucunda; Hıdırellez kutlamalarına yerel ve bölgesel turistin çok fazla ilgi gösterdiği, uzaklarda yaşayan eş dost ve akrabaların, gerek kutlamalara katılarak geleneklerini yaşama arzusu gerekse de köy halkı ile hasret giderme nedeniyle katıldıkları ifade edilmiştir. Hıdırellez kutlamalarına yerli turistlerin ilgi gösterdiği yabancı turistlerin ise yok denecek kadar az olduğu yapılan çalışmada ortaya çıkan bir diğer sonuçtur. Çanakkale iline gelen yabancı ziyaretçilerin Hıdırellez Kutlamaların olduğu zamanlarda köylere yönlendirilmeleri kültürel mirasımızın tanıtımına önemli katk1 sağlayacaktır.

Hıdırellez kutlamalarına yalnızca yerel ve bölgesel turistin yanı sıra ulusal ve uluslararası düzeyde ilgi gösterilmesi için tanıtımının yapılması gerekmektedir. Böylede geleneksel etkinliklere ilgi duyan ve yerel gastronomi ürünlerini tatmak amaciyla ziyaretlerde bulunmak isteyen turistlerin bölgeye gelmesi sağlanacaktır. Sonuç itibariye sürdürülebilir gastronomi turizmine önemli katkıları sunulurken, yerel halkın geleneklerini sürdürmesi konusunda istekleri artacaktır. Ayrıca Hıdırellez kutlamalarına turistlerin dahil edilmesi, kültürel mirasın tanıtımı ve sürdürülebilirliğine katkı sunacaktır.

Çalışmanın sadece Ayvacık ilçesine bağlı köylerde yapılmış olması bu çalışmanın kısıtlılığı olarak görülebilir. Bu nedenle bundan sonra yapılacak çalışmanın Çanakkale iline bağlı ilçe ve ilçelere bağlı köylerinde yapılması ve Çanakkale'de Hıdırellez kutlamalarında yapılan yemeklerin ortaya çıkarılmasını sağlayacaktır. Somut olmayan kültürel miras listesinde yer alan bahar bayramı Hıdırellez kutlamalarında yapılan yemeklerin tüm Türkiye'de yapılacak araştırmalar sonucunda envanterinin çıkarılması ve yapılan yöresel yemeklerin kayıt altına alınarak korunması, kültürel mirasın devamlılı̆̆ı için önemli olacaktır. Hıdırellez Pilavın kutlamalarda yapılması ve sunulması, sürdürülebilir turizm kapsamında yerel halkın turizmden gelir elde etmelerini sağlayacak önemli bir yöresel yemek haline gelebilir. Bunun yanı sıra kültürel mirasın gelecek kuşaklar tarafında bilinir kılınması ve sürdürülebilirliğinin sağlanmasını konusunda önemli bir adım olacaktır.

\section{KAYNAKÇA}

Ayaz, N., ve Çobanoğlu, S. (2017). Ev Kadınlarının Turizm Amaçlı Yöresel Yemek Üretimine Bakış Açıları: Bartın İli Örneği, Karabük Üniversitesi Sosyal Bilimler Enstitüsü Dergisi, 7 (1), $413-$ 427.

Aydoğdu, A. ve Mizrak, M. (2017). Yöresel Yemeklerin Sürdürülebilirliğinde Standart Reçetelendirmenin Önemi: Kastamonu Mutfağı Örneği, Mehmet Akif Ersoy Üniversitesi Sosyal Bilimler Enstitüsü Dergisi, 9, (20), 366-394.

Barrère, C., Bonnard, Q. and Chossat, V. (2012). Food, Gastronomy and Cultural Commons. Chapters in: Enrico Bertacchini, Giangiacomo Bravo, Massimo Marrelli and Walter Santagata (ed.), Cultural Commons, chapter 7, Edward Elgar Publishing. 
Bayrakçı, S., ve Akdağ, G. (2016). Yerel Yemek Tüketim Motivasyonlarının Turistlerin Tekrar Ziyaret Eğilimlerine Etkisi: Gaziantep'i Ziyaret Eden Yerli Turistler Üzerine Bir Araştırma, Anatolia: Turizm Araştırmaları Dergisi, 27 (1), 96-110.

Bezirgan, M., ve Koç, F. (2014). Yerel Mutfakların Destinasyona Yönelik Aidiyet Oluşumuna Etkisi: Cunda Adası Örneği, Uluslararası Sosyal Araştırmalar Dergisi, 34 (7), 919-928.

Çalışkan Şerife, S.E. (2015). Türklerde Hıdırellez İnancı: Makedonya Örneği, International Journal of Science Culture and Sport, Special Issue 3, 380-391.

Çay, A. M. (1999). Nevruz-Türk Ergenekon Bayramı, Ankara: Tamga Yayıncılık.

C,etin, İ. (2002). Türk Mitinde Kut Iyesi Kıdır ve Medeniyet Değişikliğinde Kıdır'dan Hızır'a Geçiş, Milli Folklor, 14 (7), 33-54.

Delind, L. B. (2006). Of Bodies, Place and Culture: Re: Situating Local Food, Journal of Agricultural and Environmental Ethics, 19, 121-146.

Erol M. (2004). Köy Hayırlarının Yapısal ve İşlevsel Özellikleri Üzerine Bir İnceleme: Göçalı Köyü Örneği, TÜBAR, 16, Güz Dönemi.

Gheorghe1, G., Tudorache, P. and Nistoreanu, P. (2014). Gastronomic Tourism, A New Trend for Contemporary Tourism?, Cactus Tourism Journal, 9 (1), 12-21.

http://www.unesco.org.tr/Pages/126/123/UNESCO-\%C4\%B0nsanl\%C4\%B1\%C4\%9F\%C4\%B1nSomut-Olmayan-K\%C3\%BClt\%C3\%BCrel-Miras\%C4\%B1-Temsili-Listesi. Erişim Tarihi: 23.06.2019.

Kurin, R. (2004). Safeguarding Intangible Cultural Heritage in the 2003 UNESCO Convention: A Critical Appraisal. Museum International, 56(1-2), 66-76.

Kahraman N. ve Arıkan R. (2015). Orta Asya'dan Bilecek'e Hıdırellez, Türk Dünyası İncelemeleri Dergisi, 15(1). 13-28.

Kumartaşlığlu, S. (2017). Edremit ve Burhaniye Tahtacılarında Hıdırellez, Balıkesir Üniversitesi Sosyal Bilimler Enstitü Dergisi, 20, (37), 275-291.

Lee, K.H. (2014). The Importance of Food in Vacation Decision-Making: Involvement, Lifestyles and Destination Activity Preferences of International Slow Food members, Queensland Üniversitesi, Doktora Tezi. Avustralya.

Lee, K.-H., Packer, J. and Scott, N. (2015). Travel Lifestyle Preferences and Destination Activity Choices of Slow Food Members and Nonmembers. Tourism Management, 46, 1-10.

Önal M. Naci (2010). Muğla'da Hıdırellez Bayramı, Çukurova Üniversitesi Türkoloji Araştırmaları Dergisi. 1187-1208.

Serçeoğlu, N. (2014). Yöre Halkının Mutfak Kültürünü Tanıma Durumunun Tespit Edilmesi: Erzurum İli Örneği, Journal of Tourism and Gastronomy Studies, 2 (4), 36-46.

Vanhonacker F., Verbeke W., Guerrero L., Claret A., Contel M., Scalvedi M.L., ZakowskaBiemans S., Gutkowska K., SulmontRossé C., Raude J., Granli B.S., and Hersleth M. (2010). How European consumers define the concept of traditional food: Evidence from a survey in six countries, Agribusiness, 26(4), 453-476.

Wahlqvist, M. and Lee, M.S. (2007). Regional Food Culture and Development, Asia Pac J Clin Nutr. 16(1), 2-7. 
Yıldırım, A. ve Şimşek, H. (2011). Sosyal Bilimlerde Nitel Araştırma Yöntemleri, 8. Baskı, Ankara: Seçkin.

Zağralı, E., Akbaba, A. (2015). Turistlerin Destinasyon Seçiminde Yöresel Yemeklerin Rolü: İzmir Yarımadası'nı Ziyaret Eden Turistlerin Görüşleri Üzerine Bir Araştırma, Journal of Yasar University, 10 (40), 6633-6644.

\section{Görüşmecilere İlişkin Bilgiler:}

Görüşmeci 1, Fethiye Turan 1956, Sapanca Köyü,

Görüşmeci 2, Meryem Saraç ,1978, Tuztaşı Köyü,

Görüşmeci 3, Rıza Kaya, 1955, Erecek Köyü

Görüşmeci 4, Gürcan İşhan, 1956, Ayvacık Merkez

Görüşmeci 5, Selami Yavuz, 1970, Sapanca Köyü

Görüşmeci 6, Mehmet Yahya, Yavaş, Yukarıköy

Görüşmeci 7, Ayten Balcı, 1984, Ahmetçe Köyü

Görüşmeci 8, Zihniye Toklu, 1956, Tartışık Köyü

Görüşmeci 9, Nurşen Özkan, 1957, Kayalar Köyü

Görüşmeci 10, Sevgi Gülen, 1979, Ayvacık Merkez

Görüşmeci 11, Bülent Kaya, 1967, Bilaller Köyü 